\title{
IDENTIFIKASI SENYAWA FLAVANOID DAUN SEMBUNG (Blumea balsamifera L.)
}

Ahmad Ruhardi ${ }^{*}$, Muhamad Handoyo Sahumena ${ }^{2}$

${ }^{1}$ Program Studi Kesehatan Lingkungan, Sekolah Tinggi Teknik lingkungan (STTL),Mataram, Jl. Bung Karno No.60, Pagesangan Tim., Kec. Mataram, Kota Mataram

2.Jurusan Farmasi, Fakultas Farmasi, Universitas Halu Oleo,

Jl. HEA Mokodompit, Kampus Hijau Bumi Tridharma Anduonohu, Kendari

*Penulis Korespondensi. Email: ahmad.ruhardikl@sttl-mataram.ac.id

\section{ABSTRAK}

Daun sembung (Blumea balsamifera L.) merupakan salah satu bagian tanaman dari sekian banyak tanaman yang digunakan oleh masyarakat sebagai obat tradisional untuk menjaga kesehatan sekaligus dapat menyembuhkan suatu penyakit seperti nyeri, diare dan gatalgatal. Senyawa yang berperan dalam tanaman ini adalah flavonoid. Tujuan dari penelitian ini yaitu menetapkan kadar flavonoid yang terdapat dalam ekstrak metanol daun sembung. Metode yang digunakan untuk mengidentifikasi kandungan flavonoid yaitu dengan metode Spektrofotometri UV-Vis. Analisis kadar flavonoid ekstrak metanol daun sembung dilakukan pada panjang gelombang $382 \mathrm{~nm}$ dengan nilai absorbansi secara berturut turut yaitu 0,094 ; 0,$090 ; 0,084$. Kadar total kandungan flavonoid dalam sampel dihitung dengan cara mengkalibrasi nilai absorbansi sampel dengan persamaan linear standar kuarsetin yaitu y = $0,060 \times-0,016$ dengan koefisien korelasi $\left(R^{2}\right)=0,997$ dan didapatkan rata-rata kandungan total flavonoid dalam ekstrak metanol daun sembung yaitu 0,175 \%.

\section{Kata Kunci:}

Daun Sembung (Blumea balsamifera L.); Flafanoid; Spektrofotometri UV-Vis

$\begin{array}{ccc}\text { Diterima: } & \text { Disetujui: } & \text { Online: } \\ \text { 10-02-2020 } & 24-02-2020 & 5-03-2020\end{array}$

\section{ABSTRACT}

Blumea balsamifera L. (Sembung leaf) is one of the plants used by many as a traditional medicine to maintain health and cure diseases, such as pain, diarrhea, and itching. Flavonoid is an essential compound of this plant. The purpose of this study was to determine the levels of flavonoids contained in the sembung leaf methanol extract. To identify the flavonoid content, Spectrophotometry UV-Vis method. Further, the analysis of methanol extract flavonoid in sembung leaves was carried out at a wavelength of $382 \mathrm{~nm}$ with successive absorbance values of $0.094 ; 0.090 ; 0.084$. The total content of flavonoids in the sample was calculated by calibrating the absorbance value of the example with a standard linear equation of quercetin, $y=0.060 \times-0.016$ with a correlation coefficient $(\mathrm{R} 2)=0.997$, and; the average total flavonoid content in the methanol extract of the leaves was $0.175 \%$.

Copyright (c) 2021Jsscr. All rights reserved. Keywords: Sembung Leaf (Blumea balsamifera L.); Flavanoid; UV-Vis Spectrophotometry

$\begin{array}{ccc}\text { Received: } & \text { Accepted: } & \text { Online: } \\ \text { 2020-02-10 } & 2020-02-24 & 2020-03-5\end{array}$




\section{Pendahuluan}

Indonesia adalah Negara yang letaknya berada di garis khatulistiwa. Negara yang terletak di garis ini memiliki curah hujan yang cukup tinggi dan juga termasuk di wilayah yang beriklim tropis. Sehingga keadaan ini yang membuat Indonesia kaya akan sumber daya alam yang melimpah yaitu berupa tanaman yang sangat beranekaragam. Indonesia terkenal dengan kekayaan alam yang memiliki berbagai jenis tumbuhan yang berkhasiat sebagai obat. Obat tradisional telah dikenal dan digunakan secara turun-temurun oleh masyarakat Indonesia. Pemanfaatan obat tradisional pada umumnya lebih diutamakan untuk menjaga kesehatan, meskipun pemanfaatan lainnya ditunjukan sebagai pengobatan suatu penyakit [1].

Beberapa tanaman yang ada di Indonesia mengandung senyawa metabolit sekunder yang dapat diambil untuk dijadikan obat tradisonal. Senyawa metabolit sekunder merupakan sumber bahan kimia yang tidak akan pernah habis, sebagai sumber inovasi dalam penemuan dan pengembangan obat-obat baru ataupun untuk menunjang berbagai kepentingan industri. Senyawa metabolit sekunder yang terdapat dalam tumbuhan merupakan zat bioaktif yang berkaitan dengan kandungan kimia dalam tumbuhan, sehingga sebagian tumbuhan dapat digunakan sebagai bahan obat [2].

Tanaman sembung (Blumea balsamifera) merupakan salah satu tanaman yang dapat dimanfaatkan sebagai obat tradisional, bagian tanaman ini yang sering digunakan sebagai obat adalah daunnya dan pada masyarakat daun sembung digunakan sebagai obat nyeri, diare dan gatal-gatal. Beberapa manfaat dari tanaman sembung antara lain sebagai astringent, obat diare, menambah selera makan, menguatkan lambung, obat mandi keringat untuk penderita penyakit beri-beri, obat masuk angin, nyeri haid, obat cacing dan masih banyak lagi [3].

Salah satu senyawa aktif dan memiliki kandungan khas tumbuhan hijau yang menjadi objek penelitian bagi para peneliti dalam mengembangkan obat tradisional Indonesia adalah flavonoid. Adanya kecenderungan kuat bahwa tumbuhan yang secara taksnomi berkaitan akan menghasilkan flavonoid yang serupa merupakan hal terpenting dalam penyebaran flavonoid. Untuk mendapatkan informasi tumbuhan yang diteliti dilakukan dengan melihat pustaka mengenai flavonoid terlebih dahulu dalam tumbuhan yang berkaitan, misalnya dari marga atau suku yang sama [6].

Spektrofotometer UV-Vis dapat digunakan sebagai alat untuk menganalisis kuantitatif senyawa flavonoid. Spektrum serapan ultraviolet dan serapan tampak dapat dimanfaatkan untuk mengidentifikasi senyawa flavonoid [6]. Menurut penelitian [7], mengenai penentuan kandungan flavonoid dari Ekstrak metanol daging buah mahkota dewa. Sistem aromatis yang terkonjugasi yang terkandung dalam senyawa flavonoid dapat menunjukkan serapan kuat pada daerah UV-Vis. Spektrofotometer UV-Vis digunakan dalam penelitian ini karena dapat menganalisis kadar suatu senyawa. Sehingga diharapkan dapat menganalisis kadar flavonoid dari daun sembung. Pengujian kadar senyawa flavonoid pada tanaman sembung (Blumea balsamifera L.) perlu dilakukan lebih intensif, agar potensi tumbuhan ini dapat digunakan sebagai bahan obat yang bisa dikembangkan lagi. 


\section{Metode}

Metode penelitian yang dilakukan yaitu pengumpulan bahan, pembuatan serbuk simplisia, kemudian dilakukan metode ekstraksi untuk mendapatkan ekstrak daun sembung (Blumea balsamifera L.), setelah itu dilakukan proses evaporasi. Selanjutnya dilakukan skrinining fitokimia, kemudian dilanjutkan dengan identifikasi senyawa dan analisis kadar menggunakan metode spektrofotometri UV-Vis.

\subsection{Alat dan Bahan}

Alat-alat yang digunakan dalam penelitian ini adalah batang pengaduk, blender, cawan porselin, chamber, gelas kimia, gelas ukur, gunting, hot plate, kertas saring, stirrer, Spektrofotometer UV-Vis, neraca analitik, pipa kapiler, pipet tetes, sendok tanduk, maserator, rak tabung reaksi, tabung silinder, wadah. Bahan-bahan yang digunakan dalam penelitian ini adalah metanol, etil asetat, alkohol 70\%, serbuk magnesium, etil asetat, $\mathrm{HCl}$, daun sembung (Blumea balsamifera L.), lempeng KLT , nHeksan.

\subsection{Prosedur Penelitian}

\section{a. Pembuatan Serbuk Simplisia}

Pembuatan serbuk simplisia daun sembung yaitu pertama dikumpulkan sampel yang akan digunakan. Dilakukan sortasi basah untuk memisahkan kotoran atau benda asing yang ada pada sampel. Kemudian dilakukan pencucian dengan air yang mengalir, setelah itu dikeringkan. Kemudian dirajang sampel menggunakan gunting, setelah itu dikeringkan sampel sampai benar-benar kering. Kemudian dilakukan sortasi kering untuk memisahkan kotoran atau benda asing pada sampel setelah dikeringkan. Kemudian dihaluskan simplisia menjadi serbuk simplisia menggunakan blender.

b. Ekstraksi Daun Sembung

Cara pembuatan ekstraksi simplisia daun sembung (Blumea balsamifera L.) yaitu dengan menggunakan ekstraksi dengan cara maserasi bertingkat, dimana digunakan 3 jenis pelarut yang tingkat kepolaran dari masing-masing pelarut berbeda, yaitu methanol (polar) n-heksana (non polar), etil asetat (semi polar). Pertama dilakukan penimbangan dari sampel yang digunakan sebanyak 100 gr serbuk daun sembung. Selanjutnya sampel dimasukan ke dalam wadah, kemudian ditambahkan sebanyak $1 \mathrm{~L}$ n-heksan selama 3 hari, setelah itu dilakukan penyaringan dan dilakukan dengan menggunakan kertas saring yang dapat menghasilkan filtrat n-heksan dan residu. Residu kemudian akan direndam kembali dan dilakukan dengan perlakuan yang sama menggunakan etil asetat sebagai pelarutnya, setelah itu dilakukan penyaringan kembali dengan menggunakan kertas saring untuk mendapatkan filtrat etil asetat dan residu.

Residu yang didapatkan akan direndam kembali dengan menggunakan perlakuan yang sama dimana methanol digunakan sebagai pelarutnya, setelah itu dilakukan kembali penyaringan dengan menggunakan kertas saring agar menghasilkan filtrat metanol dan residu. Kemudian masing-masing dari jenis filtrat yang didapatkan dipekatkan pada suhu $45^{\circ} \mathrm{C}$ dengan menggunakan rotary evaporator.

c. Skrining Fitokimia

Untuk uji flavonoid dilakukan dengan cara ditambahkan sampel dengan beberapa tetes magnesium dan $\mathrm{HCl}$. Selanjutnya diamati perubahan warna yang terjadi yaitu jika sampel positif mengandung senyawa akan ditandai dengan warna merah, kuning, atau jingga 


\section{d. Analisis Kadar Dengan Spektrofotometri UV-Vis}

1. Pembuatan Larutan Standar Kuarsetin

Dilakukan penimbangan sebanyak $10 \mathrm{mg}$ baku standar kuersetin yang digunakan dan dilarutkan dalam metanol p.a sebanyak $10 \mathrm{ml}$ yang digunakan untuk 1000 ppm. Dari larutan standar kuarsetin 1000 ppm tersebut, dipipet sebanyak $1 \mathrm{~mL}$ yang dilarutkan kedalam metanol p.a sebanyak $10 \mathrm{~mL}$ yang digunakan untuk $100 \mathrm{ppm}$, setelah itu dilakukan pembuatan beberapa konsentrasi yang berbeda yaitu 2 ppm, 4 ppm, 6 ppm, 8 ppm, dan 10 ppm. Pada masing-masing konsentrasi yang digunakan pada larutan standar kuersetin ditambahkan metanol sebanyak $3 \mathrm{~mL}, 0,2 \mathrm{~mL}$ kalium asetat $1 \mathrm{M}, 0,2$ $\mathrm{mL} \mathrm{AlCl} 310 \%$ yang kemudian dicukupkan dengan aquadestilata sampai 10 mL. kemudian dilakukan inkubasi dengan suhu kamar selama 30 menit dan dilakukan pengukuran terhadap nilai absorbansi pada alat spektrofotometri UV-Vis.

2. Optimasi Panjang Gelombang

Optimasi panjang gelombang dilakukan yaitu untuk mengetahui panjang gelombang maksimum yang akan digunakan dalam pengukuran kadar sampel ekstrak daun sembung (Blumea balsamifera L.) menggunakan spektrofotometri UV-Vis. Serapan dari salah satu konsentrasi larutan standar kuarsetin yang digunakan, kemudian dilakukan pengukuran dengan rentang panjang 200-700 $\mathrm{nm}$. Panjang gelombang maksimum ditunjukan dengan nilai serapan yang paling tinnggi.

3. Preparasi Sampel Ekstrak Daun Sembung (Blumea balsamifera L.)

Dilakukan penimbangan sebanyak $10 \mathrm{mg}$ dari ekstrak yang digunakan, kemudian dilarutkan dalam metanol sebagai pelarut sebanyak $10 \mathrm{~mL}$, agar dapat diperoleh konsentrasi 1000 ppm. Dari larutan tersebut dipipet $1 \mathrm{~mL}$ kemudian dicukupkan volume sampai $10 \mathrm{~mL}$ sehingga diperoleh konsentrasi $100 \mathrm{ppm}$. Diencerkan lagi menjadi $10 \mathrm{ppm}$ dengan cara mempipet $1 \mathrm{~mL}$ dari larutan 100 ppm kemudian dicukupkan volume sampai $10 \mathrm{~mL}$. Metode spektrofotometri UV-Vis merupakan suatu metode yamg digunakan dalam menentukan nilai absorbansi pada panjang gelombang maksimum tertentu.

4. Penetapan Kadar Senyawa Flavonoid dalam Sampel Ekstrak Daun Sembung (Blumea balsamifera L.)

Konsentrasi dari senyawa flavonoid pada sampel yang digunakan dapat ditentukan setelah dilakukan pengukuran nilai serapan berdasarkan persamaan regresi terhadap kurva baku kalibrasi standar. Kadar senyawa flavonoid dalam sampel ektrak daun sembung (Blumea balsamifera L.) dapat dihitung dengan rumus :

Kadar Senyawa Flavonoid $=$ X $(\mathrm{mg} / \mathrm{mL}) \times$ volume $(\mathrm{mL}) /$ Berat sampel $(\mathrm{g})$

3. Hasil dan Pembahasan

\subsection{Ekstraksi}

Hasil ekstraksi daun sembung (Blumea balsamifera L.) menunjukkan bahwa sampel sebanyak 100 gram yang diekstraksi secara maserasi dengan 3 pelarut yang berbeda yaitu n-heksan, etil asetat dan metanol sebanyak $1000 \mathrm{~mL}$ menghasilkan berat ekstrak n-heksan sebanyak 4 gram dengan persen rendamen $4 \%$, etil asetat sebanyak 8 gram dengan persen rendamen $8 \%$ dan methanol sebanyak 11,7 gram dengan persen rendamen $11,7 \%$. Hasil ekstraksi tertuang pada tabel 1. 
Tabel 1. Persen Rendamen Ekstrak Daun Sembung (Blumea balsamifera L.)

$$
\text { Pelarut Berat Sampel (g) Berat Ekstrak (g) Rendamen (\%) }
$$

\begin{tabular}{cccc}
\hline n-Heksan & 100 & 4 & 4 \\
\hline Etil Asetat & 100 & 8 & 8 \\
\hline Metanol & 100 & 11,7 & 11,7 \\
\hline
\end{tabular}

Perbedaan jenis pelarut mempengaruhi jumlah ekstrak yang dihasilkan. Pelarut polar akan menarik senyawa yang bersifat polar, sedangkan pelarut non-polar akan menarik senyawa non-polar dan pelarut semi polar akan menarik senyawa polar [8]. Ekstrak menggunakan pelarut metanol (polar) memiliki rendemen paling tinggi, diikuti rendemen ekstrak dengan menggunakan pelarut etil asetat (semi polar) dan rendemen ekstrak dengan menggunakan pelarut n-heksana (nonpolar). Metanol memiliki gugus polar yang lebih kuat dari pada gugus nonpolar, hal ini dapat terlihat dari struktur kimia metanol yang mengandung gugus hidroksil (polar) dan gugus karbon (nonpolar) [9]. Metanol dapat mengekstrak senyawa fitokimia dalam jumlah yang lebih banyak [10]. Hasil Rendemen pada pelarut etil asetat lebih kecil dibandingkan dengan pelarut metanol namun lebih besar dari pelarut n-heksana, hal ini diduga adanya gugus metoksi yang terdapat pada struktur kimia etil aseat. Adanya gugus metoksi tersebut yang menyebabkan etil asetat dapat membentuk ikatan hidrogen dengan senyawa yang terdapat pada sampel. Ikatan hidrogen yang terbentuk pada pelarut etil asetat lebih lemah dibandingkan dengan ikatan hidrogen yang terbentuk pada pelarut metanol sehingga mempengaruhi hasil rendemen dari pelarut etil asetat yang lebih sedikit. Nilai rendemen terkecil terdapat pada fraksi terlarut n-heksana, hal ini menunjukkan bahwa senyawa bioaktif yang bersifat nonpolar pada sampel daun sembung jumlahnya sedikit. Persen nilai rendemen yang didapatkan masuk dalam range persen rendemen yaitu 10-15\% yang menunjukkan bahwa proses ekstraksi daun sembung (Blumea balsamifera L.) berlangsung secara optimal [11].

3.2 Skrining Fitokimia

Penelusuran senyawa kimia melalui skrining fitokimia menunjukkan bahwa ekstrak daun sembung (Blumea balsamifera L.) menggunakan pelarut metanol mengandung golongan senyawa flavonoid. Hasil skrining fitokimia ditampilkan pada tabel 2.

Tabel 2. Hasil Skrining Fitokimia Senyawa Flavonoid dalam Ekstrak Daun Sembung (Blumea balsamifera L.)

\begin{tabular}{ccc}
\hline Ekstrak & Pereaksi & Hasil \\
\hline n-heksan & Magnesium $+\mathrm{HCl}$ & $(-)$ Flavonoid \\
& & Tidak terjadi perubahan warna \\
\hline Etil Asetat & Magnesium $+\mathrm{HCl}$ & $(-)$ Flavonoid \\
& & Tidak terjadi perubahan warna \\
\hline Methanol & Magnesium $+\mathrm{HCl}$ & $(+)$ Flavonoid \\
& & Terjadi perubahan warna ekstrak menjadi merah \\
\hline
\end{tabular}

Hal ini dapat dilihat pada tabel di atas yaitu ketika ekstrak metanol daun sembung direaksikan dengan pereaksi magnesium $+\mathrm{HCl}$ terjadi perubahan warna ekstrak menjadi merah. Penambahan $\mathrm{HCl}$ pekat dalam uji flavonoid digunakan untuk menghidrolisis flavonoid menjadi aglikonnya, yaitu dengan menghidrolisis O-glikosil. Glikosil akan tergantikan oleh $\mathrm{H}^{+}$dari asam karena sifatnya yang elektrofilik. 
Glikosida berupa gula yang biasa dijumpai yaitu glukosa, galaktosa dan raminosa. Reduksi dengan $\mathrm{Mg}$ dan $\mathrm{HCl}$ pekat ini menghasilkan senyawa komplek yang berwarna merah atau jingga pada flavonol, flavon, flavonolol, dan xanton. Warna merah yang dihasilkan menandakan adanya flavonoid akibat dari reduksi oleh asam klorida pekat dan magnesium [12].

3.3 Penentuan Panjang Gelombang Maksimal Asam Mefenamat

Dari hasil pengukuran panjang gelombang maksimal quarsetin pada rentang panjang gelombang $200-400 \mathrm{~nm}$ diperoleh serapan maksimal pada panjang gelombang $382 \mathrm{~nm}$ dengan nilai serapan sebesar 0,405. Hasil pengukuran panjang gelombang maksimal larutan baku kuarsetin yang diperoleh sama dengan panjang gelombang literatur yang ada yaitu $382 \mathrm{~nm}$ [16].

\subsection{Identifikasi Menggunakan Spektrofotomteri UV-Vis}

Pembuatan kurva kalibrasi menggunkan variasi konsentrasi 2,4,6,8 dan 10 ppm. Berdasarkan data hasil dari perhitungan regresi linear pembanding kuarsetin diatas diperoleh persamaan regresi linear yaitu $y=0,060 \times-0,016$ dengan koefisien korelasi $(R 2)=0,997$. Berikut ditampilkan hasil pemuatan kurva kalibrasi pada tabel 1 .

Tabel 4. Hasil Pembacaan Nilai Absorbansi Larutan Baku Kuarsetin Menggunakan Spektrofotometri UV-Vis

\begin{tabular}{ccc}
\hline No & Konsentrasi $(\mathbf{p p m})$ & Absorbansi \\
\hline $\mathbf{1}$ & 2 & 0.116 \\
\hline $\mathbf{2}$ & 4 & 0.217 \\
\hline $\mathbf{3}$ & 6 & 0.337 \\
\hline $\mathbf{4}$ & 8 & 0.463 \\
\hline $\mathbf{5}$ & 10 & 0.597 \\
\hline
\end{tabular}

Digunakan kuarsetin sebagai larutan standar karena kuersetin merupakan flavonoid golongan flavonol yang mempunyai gugus keto pada C-4 dan memiliki gugus hidroksil pada atom C-3 atau C-5 yang bertetangga dari flavon dan flavonol selain itu kuarsetin juga merupakan salah satu jenis flavonoid yang digunakan sebagai standar dalam pengukuran kadar senyawa flavonoid [15].

Hasil perhitungan kadar ditampilkan pada tabel 5. Berdasarkan hasil perhitungan kadar menunjukkan bahwa kadar senyawa flavonoid dalam 10 gram ekstrak metanol daun sembung (Blumea balsamifera L.) pada konsentrasi 1000 ppm dengan nilai absorbansi yang didapat 0,$094 ; 0,090 ; 0,084$ secara berturut-turut adalah 0,00183; 0,$00176 ; 0,00167$ dengan presentase secara berturut-turut $0,183 \% ; 0,176 \% ; 0,167 \%$.

Tabel 5. Kandungan Senyawa Flavonoid dalam Ekstrak Metanol daun Sembung (Blumea balsamifera L.)

\begin{tabular}{cccc}
\hline $\begin{array}{c}\text { Berat } \\
\text { Ekstrak }\end{array}$ & $\begin{array}{c}\text { Nilai Absorbansi } \\
\text { Daun Sembung } \\
\mathbf{1 0 0 0} \mathbf{~ p p m}\end{array}$ & $\begin{array}{c}\text { Kadar Senyawa } \\
\text { Flavonoid }\end{array}$ & $\begin{array}{c}\text { Presentase Kadar } \\
\text { Senyawa } \\
\text { Flavonoid }\end{array}$ \\
\hline \multirow{2}{*}{$\mathbf{1 0} \mathbf{~ m g}$} & 0,094 & 0,00183 & $0,183 \%$ \\
\cline { 2 - 4 } & 0,090 & 0,00176 & $0,176 \%$ \\
\hline & 0,084 & 0,00167 & $0,167 \%$
\end{tabular}


Senyawa yang banyak terkandung dalam daun sembung yaitu flavonoid. Senyawa turunan flavonoid yang terkandung dalam tanaman sembung antara lain blumeatin (5,3', 5' trihydroxy-7-methoxy-dihydro-flavone), velutin, tamarixetin, dihidrokuersetin7,4'-dimetil eter, ombuine, rhamnetin, luteolin-7-metil eter, luteolin, kuersetin, $5,7,3^{\prime}, 5^{\prime}$ tetrahidroksiflavanon, dan dihidrokuersetin-4' metil eter [5].

\section{Kesimpulan}

Berdasarkan hasil penelitian yang telah dilakukan didapatkan bahwa dalam $10 \mathrm{mg}$ ekstrak metanol daun sembung (Blumea balsamifera L.) memiliki kadar senyawa flavonoid total sebanyak 0,00175 dengan presentase $0,175 \%$.

Referensi

[1] Suharmiati. 2003. Pengujian Bioaktifitas Anti Diabetes Melitus Tumbuhan Obat. Cermin Dunia Kedokteran. Surabaya : Departemen Kesehatan RI

[2] Adikara, I Putu Arya dkk. 2013. Studi Histopatologi Hati Tikus Putih (Rattus novergicus) yang diberi Ekstrak Etanol Daun Kedondong (Spondias dulcis) Secara Oral. Buletin Vateriner Udayana

[3] Heyne, K. 1987. Tumbuhan Berguna Indonesia, Volume II, Yayasan Sarana Wana Jaya :Diedarkan oleh Koperasi Karyawan. Jakarta : Badan Litbang Kehutanan

[4] Pang et al. 2014. Anti Diarrhea and Antioxidant Activities of Honokiol Extract from Magnoliae Officinalis Cortex in mice.

[5] Nessa F, Ismail Z, Karupiah S, Mohamed N. 2005. RP-HPLC method for the quantitative analysis of naturally occurring flavonoids in leaves Blumea Balsamifera DC. J Chromatogrsci

[6] Markham, K.R., 1988, Cara Mengidentifikasi Flavonoid, diterjemahkan oleh Kosasih Padmawinata. Bandung : ITB

[7] Rohyami Y. 2008. Penentuan Kandungan Flavonoid dari Ekstrak Metanol Daging Buah Mahkota Dewa. Yogyakarta : Universitas Islam Indonesia

[8] Depkes RI. 1986. Sediaan Galenik, 2 E10. Jakarta : Departemen Kesehatan RI

[9] Ukhty N. 2011. Kandungan Senyawa Fitokimia Total Fenol Dan Aktivitas Antioksidan Lamun (Syrongodium isoetifolium). Bogor : Institut Pertanian Bogor

[10] Supiyanti W. Wulansari ED dan Kusmita L. 2010. Uji Aktivitas Antioksidan Dan Penentuan Kandungan Antosianin Total Kulit Buah Manggis (Garcinia mangostana L.). Farmasi

[11] Vitasari, E W. 2013. Antihiperlipidemia Ekstrak Etanol Batang Kayu Kuning (Arcangelisia flafa (L.) Merr.) Terhadap Tius Putih Galur Wistar Yang Diinduksi Pakan Tinggi Lemak. Semarang : Sekolah Tinggi Ilmu Farmasi "Yayasan Farmasi"

[12] Robinson, T., 1985. Kandungan Organik Tumbuhan Tinggi Edisi VI. Bandung : Institut Teknologi Bandung 
[13] Peter Lipsy, 2010. Thin Layer Chromatography Characterization of the Active Ingredients in Excedrin and Anacin. In Departmentof Chemistry and Chemical Biology, Stevens Institute of Technology: Castle Point on Hudson

[14] Harborne, J.B. 1987. Metode Fitokimia Penuntun Cara Modern Menganalisis Tumbuhan. Bandung : ITB

[15] Azizah, Dyah, dkk. 2014. Penetapan Kadar Flavonoid Metode Alcl3 Pada Ekstrak Metanol Kulit Buah Kakao (Theobroma Cacao L.). Bandung : Universitas Jenderal Achmad Yani

[16] Buchweitz, M., Kroon, P. A., Rich, G. T., \& Wilde, P. J. (2016). Quercetin solubilisation in bile salts: A comparison with sodium dodecyl sulphate. Food chemistry, 211, 356-364. 